\title{
ODSZKODOWAWCZY CHARAKTER WYNAGRODZENIA ZA SŁUŻEBNOŚĆ PRZESYŁU
}

\section{WPROWADZENIE}

Budowa i utrzymywanie urządzeń przesyłowych ${ }^{1}$ na cudzej nieruchomości istotnie wpływa na sytuacje prawną jej właściciela, powodując zazwyczaj powstanie uszczerbku na jego mieniu. Uszczerbek ten na etapie procesu budowy urządzeń jest najczęściej związany z ingerencją w substancję rzeczy (np. W związku z naruszeniem struktury gruntu na skutek wjazdu specjalistycznego sprzętu i prowadzonych prac czy zniszczeniem w istniejących uprawach, zabudowie). Może on także wynikać ze zmniejszenia wartości nieruchomości, jako rzeczy zabudowanej urządzeniami przesyłowymi. Z kolei na etapie utrzymywania urządzeń przesyłowych na cudzej nieruchomości uszczerbek na mieniu może powstać w związku z ograniczeniami dotyczącymi korzystania z niej, zarówno w obszarze bezpośrednio zajętym pod urządzeniami, jak i wyznaczonym tzw. pasie służebności (stanowi go np. utrata korzyści w związku z ograniczeniami w uprawach czy ograniczeniami w zabudowie nieruchomości).

W powyższym kontekście doniosłe stają się rozważania nad wpływem zapłaty wynagrodzenia za służebność przesyłu na rzecz właściciela nieruchomości na zakres odpowiedzialności odszkodowawczej przedsiębiorcy przesyłowego za uszczerbki powstałe $\mathrm{w}$ związku z budową i utrzymywaniem urządzeń przesyłowych. We wstępie należy bowiem postawić tezę, że wynagrodzenie za służebność przesyłu - mimo że nie stanowi stricte odszkodowania - ma swoisty charakter odszkodowawczy, a jego zapłata kompensuje uszczerbki doznane przez właściciela nieruchomości związane z lokalizowanymi urządzeniami przesyłowymi, w zakresie omówionym w niniejszym artykule.

\section{WYNAGRODZENIE ZA SŁUŻEBNOŚCI PRZESYŁU - ZAGADNIENIA OGÓLNE}

Służebność przesyłu stanowi ograniczone prawo rzeczowe, które może być ustanowione na rzecz przedsiębiorców będących właścicielami urządzeń, do których odnosi się art. 49 k.c., bądź mających zamiar je wybudować. Pomi-

1 A więc urządzeń określonych w art. $49 \S 1$ k.c. 
mo że nie jest to sprecyzowane w unormowaniach kodeksowych, służebność przesyłu swoją treścią obejmuje prawo do wybudowania urządzeń przesyłowych, ich utrzymywania na nieruchomości, eksploatacji, a nadto dokonywania niezbędnych konserwacji i napraw ${ }^{2}$. W przypadku umownego sposobu kreacji służebność przesyłu może być ustanawiana za wynagrodzeniem bądź bez wynagrodzenia ${ }^{3}$. Wobec nabycia tejże służebności w drodze zasiedzenia, co umożliwia art. 292 w zw. z art. 305(4) k.c., nie przysługuje właścicielowi nieruchomości żaden ekwiwalent od nabywcy służebności ex lege $e^{4}$.

Odrębnym zagadnieniem jest określenie wynagrodzenia w przypadku, gdy służebność jest ustanawiana na podstawie art. $305^{2}$ k.c., w ramach sądowego sposobu dochodzenia roszczenia o ustanowienie służebności. Szczegółowe omówienie tej kwestii wykraczałoby jednak poza ramy niniejszych rozważań ${ }^{5}$. Wymaga jednak odnotowania, że obowiązek jego zapłaty nie stanowi treści służebności przesyłu, a wynika ze stosunku obligacyjnego powstałego z mocy orzeczenia sądu albo na podstawie zawartej między stronami umowy ${ }^{6}$.

Unormowania kodeksowe, w szczególności art. $305^{2}$ k.c., w sposób ascetyczny odnoszą się do zasad określania wynagrodzenia za służebność przesyłu, wskazując jedynie, że ma być ono odpowiednie. Jeżeli wynagrodzenie za służebność jest określane w pieniądzu , jak dzieje się zawsze w przy-

${ }^{2}$ W orzecznictwie zauważa się, że na ogół wykonywanie służebności polega na przeprowadzeniu przez daną nieruchomość urządzenia przesyłowego oraz dokonywaniu modernizacji, remontów itp., przy czym czynności te mogą być wykonywane z różną częstotliwością - tak postanowienie SN z 20 kwietnia 2017 r., II CSK 505/16, Lex nr 2331704.

${ }^{3}$ Wyjątek stanowi szczególna regulacja art. 39 a ust. 1 ustawy z 28 września 2001 r. o lasach (t.jedn.: Dz. U. 2018, poz. 2129) Należy wywodzić, że służebność przesyłu ustanawiane na tej podstawie jest zawsze prawem odpłatnym, nawet jeżeli jej źródłem jest umowa - zob. Balwicka-Szczyrba (2015): 213, także Lewandowski (2014): 68.

${ }^{4}$ W wyrokach TK z 25 maja 1999 r., SK 9/98, OTK 1999, nr 4, poz. 78, i z 14 grudnia 2005 r., SK 61/03, OTK-A 2005, nr 11, poz. 136 - potwierdzono, że zasiedzenie jest usprawiedliwione ochroną porządku publicznego i przepisy o zasiedzeniu, mimo że nie przewidują rekompensaty dla właściciela utraconej własności, są zgodne z art. 31 ust. 3 Konstytucji, a w przypadku nabycia służebności gruntowej przez zasiedzenie - także z art. 64 ust. 3 Konstytucji, zob. także uzasadnienie uchwała SN z 30 listopada 2016 r., III CZP 77/16, OSNC 2017, nr 9, poz. 94, oraz Matusik (2013): 397; odmiennie - i jak się wydaje nietrafnie - Radziwilski (2011): 129-130.

${ }^{5} \mathrm{Na}$ marginesie należy tylko podkreślić, że wynagrodzenie za służebność jest elementem koniecznym postanowienia sądu orzekającego o jej ustanowieniu. Postanowienie o ustanowieniu służebności przesyłu i o wynagrodzeniu za ustanowienie tego prawa są ze sobą integralnie powiązane, co oznacza, że komplementarnymi elementami orzeczenia jest zarówno ustanowienie służebności przesyłu, jak i rozstrzygnięcie o wynagrodzeniu (tak SN w postanowienie z 18 maja 2016 r., V CSK 531/15, Lex nr 2076691). Ustanowienie służebności przesyłu na drodze sądowej co do zasady jest odpłatne, określenie zaś wysokości i rodzaju wynagrodzenia jest elementem koniecznym orzeczenia kształtującego, jakim jest postanowienie o ustanowienie służebności przesyłu (zob. postanowienie SN z 18 kwietnia 2012 r., V CSK 190/11, Lex nr 1212828). Z punktu widzenia aksjologicznego nie można jednak wykluczyć sytuacji, gdy właściciel nieruchomości obciążonej zrzeka się wynagrodzenia za ustanowienie służebności przesyłu. Zrzeczenie się takie musiałoby być wyraźne i winno podlegać badaniu przez sąd co do jego skuteczności, np. z punktu widzenia wad oświadczenia woli.

${ }^{6}$ Zob. Balwicka-Szczyrba (2015): 137.

7 Dopuszcza się bowiem ustalenie tegoż wynagrodzenia w naturze; zob. Balwicka-Szczyrba (2015): 139 i tam powołana literatura. 
padku sądowego sposobu ustanawiania służebności, trudność budzi sposób ustalenia jego wysokości. Należy przede wszystkim wskazać, że brak stałych algorytmów pozwalajacych na jego oszacowanie, choć propozycje wprowadzenia takowych sa podnoszone w nauce ${ }^{8}$. W szczególności Piotr Lewandowski postuluje, aby wprowadzony został obiektywny mechanizm jego ustalania, co miałoby nastapić w drodze rozporządzenia Rady Ministrów ${ }^{9}$. Propozycję stałego algorytmy należy poddać krytyce, chociażby dlatego, że nie uwzględniała ona okoliczności danej sprawy, przy różnorodności stanów faktycznych związanych z posadawianiem i utrzymywaniem urządzeń przesyłowych ${ }^{10}$. Wymaga nadto zauważyć, że brak podobnych rozwiązań w przypadkach dotyczacych innych niż służebność przesyłu rodzajów służebności, które także mogą być ustanawiane za wynagrodzeniem. Zwłaszcza art. 145 k.c., regulujący służebność drogi koniecznej, czyli także służebność przymusową - nie odwołuje się przy określaniu wynagrodzenia za ustanowiona służebność do żadnych algorytmów ani innych mechanizmów jego ustalania. Tutaj bogate orzecznictwo sądowe pomaga w przypadku watpliwości w tym zakresie ${ }^{11}$.

W związku z powyższym należy odnotować, że uznaniu stron umowy o ustanowienie służebności przesyłu pozostawiono wysokość wynagrodzenia za służebność. Strony, za obopólna zgoda, mogą wysokość tę określić dowolnie. Jeżeli służebność przesyłu jest ustanawiana w trybie sądowym, co może się zdarzyć także w przypadku braku porozumienia stron w zakresie tego wynagrodzenia, jego wysokość pozostaje w gestii oceny sądu orzekającego, który wspiera się zazwyczaj opinią biegłego sądowego z zakresu szacowania nieruchomości dysponującego kompetencjami w zakresie szacowania wynagrodzenia za ustanowienie służebności przesyłu ${ }^{12}$. Jedyną wskazówką co do jego wysokości jest cecha „odpowiedniości”, do której odwołuje się art. $305^{2}$ k.c., o czym mowa będzie poniżej.

${ }^{8}$ Zob. Balwicka-Szczyrba (2015): 142, 404-405 i tam przytoczone stanowiska.

${ }^{9}$ Zob. Lewandowski (2014): 231.

${ }_{10}$ Balwicka-Szczyrba (2015): 142

${ }^{11}$ Zob. m.in. postanowienia SN: z 14 marca 2012 r., II CSK 371/11, Lex nr 1215144; z 5 kwietnia 2012 r., II CSK 401/11, Lex nr 1211144; z 27 lutego 2013 r., IV CSK 440/12, Lex nr 1294169; z 9 października 2013 r., V CSK 491/12, Lex nr 1394096; z 26 marca 2018 r., I CSK 701/17, Lex nr 2508137; z 20 kwietnia 2017 r., II CSK 505/16, Lex nr 2331704; z 6 kwietnia 2018 r., IV CSK 540/17, Lex nr 2497679; z 8 maja 2018 r., V CSK 614/17, Lex nr 2500517; z 6 września 2018 r., V CSK 437/17, Lex nr 2579529.

${ }^{12}$ Wymaga odnotowania, że zasady ustalania wynagrodzenia za służebność przesyłu nie zostały ujęte w unormowaniach dotyczących wyceny nieruchomości i sporządzaniu operatów szacunkowych, w tym w rozporządzeniu Rady Ministrów w sprawie wyceny nieruchomości i sporządzaniu operatu szacunkowego z 21 września 2004 r., Dz. U. 2004, Nr 207, poz. 2109 ze zm. - zob. Matusik (2013): 396-397; warto jednak wskazać, że Polska Federacja Stowarzyszeń Rzeczoznawców opracowała Krajowy Standard Wyceny Specjalistyczny dotyczący „określania wartości służebności przesyłu i wynagrodzenia za jej ustanowienie oraz wynagrodzenia za bezumowne korzystanie z nieruchomości przez przedsiębiorców przesyłowych"; standard ten jest zalecany do stosowania od 1 stycznia $2017 \mathrm{r}$. 


\section{CHARAKTER WYNAGRODZENIA ZA SŁUŻEBNOŚĆ PRZESYŁU}

Istota wynagrodzenia za służebność przesyłu jest w nauce zagadnieniem spornym $^{13}$. Wątpliwości budzi zwłaszcza, czy wynagrodzenie to stanowi stricte odszkodowanie, czy jest to pojęcie odmienne ${ }^{14}$. W tym drugim przypadku nie jest jasny stosunek terminu „odszkodowanie” do terminu „wynagrodzenie”, a zwłaszcza jakie inne okoliczności niż uszczerbek doznany przez właściciela nieruchomości powinny być brane pod uwagę przy jego ustalaniu. Wymaga wskazania, że problematyka związana z istota wynagrodzenia za służebność przesyłu sama w sobie nie jest zagadnieniem nowym, albowiem podobne watpliwości podnoszono między innymi przy analizie art. 145 k.c. co do wynagrodzenia za służebność drogi koniecznej ${ }^{15}$.

Jednej z przyczyn wskazanych powyżej wątpliwości terminologicznych należy szukać po stronie samego ustawodawcy. Zdarzało się (i zdarza obecnie), że ustawa przyznaje roszczenie o odszkodowanie bądź też roszczenie o wynagrodzenie w podobnych stanach faktycznych, co prowadzi do ich mylnego traktowania przez praktykę jako pojęć tożsamych. Zjawisko to można zauważyć już przy analizie unormowań dotyczacych służebności drogi koniecznej, a także innych unormowań ${ }^{16}$. Co do służebności drogi koniecznej art. $33 \S 1$ dekretu z 11 października 1946 r. - Prawo rzeczowe posługiwał się pojęciem odszkodowania, które należne było za ustanowienie tejże służebności. Obecnie obowiązujacy art. 145 k.c., w podobnych okolicznościach prowadzących do ustanowienia prawa, przyznaje właścicielowi nieruchomości za ustanowiona służebność prawo do wynagrodzenia.

Kolejny przykład stanowi art. 124 u.g.n., będący podstawą przyznania przedsiębiorcom przesyłowym uprawnienia do korzystania z cudzych nieruchomości w związku z budowanymi urządzeniami przesyłowymi, w drodze decyzji administracyjnej starosty ${ }^{17}$. Przewiduje on w ust. 4 majacy charakter odszkodowawczy obowiązek restitutio in integrum - przywrócenia nieruchomości do stanu poprzedniego, niezwłocznie po założeniu lub przeprowadzeniu ciągów, przewodów i urządzeń, o których mowa w ust. 1. Gdy zaś przywrócenie nieruchomości do stanu poprzedniego jest niemożliwe albo powoduje nadmierne trudności lub koszty, przepis ust. 4 zawiera odesłanie do odpowiedniego stosowania przepisu art. 128 ust. 4 u.g.n. Norma wynikająca z tego przepisu kreuje z kolei uprawnienie do odszkodowania za szkody powstałe wskutek zdarzeń, o których mowa m.in. w art. 124 u.g.n., przy czym odszkodowanie powinno odpowiadać wartości poniesionych szkód.

W podobnych okolicznościach, choć zarówno w związku z istniejącymi już, jak i nowo budowanymi urządzeniami przesyłowymi ${ }^{18}$, Kodeks cywilny

${ }^{13}$ Por. m.in. Matusik (2013): 395; Wdowiak (2012): 157-167; Jędrejek (2009): 28 n.

${ }_{14}$ Zob. na ten temat: Balwicka-Szczyrba (2015): 142.

15 Zob. m.in. Warciński (2010): 57-67.

${ }_{16}$ Por. m.in. roszczenia z art. 224 i 225 k.c.

${ }^{17}$ Decyzja ta jest wydawana w ramach tzw. małego wywłaszczenia.

${ }_{18}$ Decyzję starosty z art. 124 ust. 1 u.g.n. można pozyskać jedynie w zakresie nowych inwestycji przesyłowych. 
umożliwia pozyskanie przez przedsiębiorców przesyłowych prawa innego co do istoty, lecz podobnego, jeżeli chodzi o zakres uprawnień do nieruchomości, tj. służebności przesyłu ${ }^{19}$. W tym jednak przypadku za ustanowienie służebności, w drodze postępowania sądowego, należy się odpowiednie wynagrodzenie.

Powyżej wskazane przykłady oddziałują na praktykę stosowania prawa. Nierzadko można odnotować zamienne operowanie terminami „wynagrodzenie” i „odszkodowanie” należne za ustanowienie służebności, w tym służebności przesyłu. Niewątpliwie nie jest to zabieg prawidłowy, albowiem zakresy obu pojęć nie odpowiadają sobie.

W tym miejscu warto podzielić zapatrywanie, że wynagrodzenie za służebność jest terminem szerszym od odszkodowania i - jak się niekiedy wskazuje - bardziej elastycznym ${ }^{20}$. Trafnie zauważa się, że ustawodawca posługuje się terminem „wynagrodzenie” w różnych stanach faktycznych, co przemawia za dużą pojemnością tego pojęcia ${ }^{21}$. Za przyjętym zapatrywaniem przemawiają zwłaszcza argumenty językowe. Jeżeli racjonalny ustawodawca chciałby, aby za korzystanie z nieruchomości, w związku z ustanowioną służebnościa, należało się jedynie odszkodowanie, to wprost by to określił. W sytuacji gdy operuje on pojęciem wynagrodzenia, należy uznać to za działanie zamierzone. Po drugie, gdyby świadczenie należne na mocy art. $305^{2}$ k.c. było stricte odszkodowaniem, jego dochodzenie należałoby poddać jednemu z reżimów odpowiedzialności odszkodowawczej, z czym związany byłby obowiązek wykazania zdarzenia wyrządzającego szkodę, doznanego uszczerbku, a nadto adekwatnego związku przyczynowego między nimi. Trafnie wskazuje Sąd Najwyższy w uchwale z 2 czerwca $2010 \mathrm{r}^{22}$, że ustawodawca posługuje się wynagrodzeniem w miejsce odszkodowania dla podkreślenia, że obowiązek naprawienia uszczerbku nie wynika z odpowiedzialności kontraktowej lub odpowiedzialności za czyn niedozwolony. Wydaje się, że byłoby to nadmierne utrudnienie prowadzące w niektórych przypadkach do oddalenia roszczenia właściciela nieruchomości z uwagi na niewykazanie przesłanek roszczenia odszkodowawczego. Przyjęcie, że za służebność przesyłu należy się wynagrodzenie, a nie stricte odszkodowanie, niewątpliwie poprawia procesową sytuację właścicieli nieruchomości.

Z powyższych powodów nie można za trafny uznać poglądu wyrażonego w uchwale SN z 2 czerwca 2010 r. ${ }^{23}$, w której wskazuje się, że wynagrodzenie nie może przenosić wysokości odszkodowania ${ }^{24}$. Należy przyjmować wręcz odmiennie, że w przypadku ustanowienia służebności przesyłu wynagrodzenie to zazwyczaj wysokość odszkodowania przenosi, albowiem kompensuje ono

19 Odnośnie do różnic i podobieństw w zakresie przyznawanych uprawnień do nieruchomości zob. Balwicka-Szczyrba (2015): 108-109, 218-219.

${ }_{20}$ Tak m.in. Matusik (2013): 400; por. także m.in. Kubas (1966): 349-350; Warciński (2010): 61; Karaszewski (2014): 89.

21 Zob. Konieczny, Kowalczyk (2010): 58-59.

22 Uchwała SN z 2 czerwca 2010 r., III CZP 36/10, OSNC 2010, nr 12, poz. 163.

${ }^{23}$ Uchwała SN z 2 czerwca 2010 r., III CZP 36/10. Pogląd wyrażony odnośnie do wynagrodzenia za zmianę treści służebności przesyłu.

24 Podobne zapatrywania można spotkać na gruncie art. 145 k.c. - zob. postanowienie SN z 13 grudnia 2012 r., V CSK 3/12, Lex nr 1314483. 
nie tylko doznane przez właściciela nieruchomości uszczerbki, lecz także inne dolegliwości związane z ustanawianą służebności ${ }^{25}$. Jak wskazuje Grzegorz Karaszewski, na gruncie unormowania dotyczącego służebności drogi koniecznej wynagrodzenie za służebność stanowi nie tylko rekompensatę za korzystanie z cudzej nieruchomości, lecz także stanowi kwotę uiszczaną dodatkowo, ponad wysokość szkody, tytułem swoistej sankcji cywilnej26. Powyższe zapatrywanie znajduje aktualność także odnośnie do wynagrodzenia za służebność przesyłu, chociażby dlatego, że wynagrodzenie za służebność drogi koniecznej pełni taka samą funkcję co wynagrodzenie za służebność przesyłu ${ }^{27}$. Aktualność odnośnie do istoty tegoż drugiego zachowują więc wywody o istocie tego pierwszego.

Mimo że wynagrodzenie za służebność przesyłu nie stanowi stricte odszkodowania, nie można mu odebrać funkcji odszkodowawczeje ${ }^{28}$. Skoro „wynagrodzenie” zawiera w sobie „odszkodowanie”, oznacza to, że pokrywa ono uszczerbki majątkowe związane z ustanawianą służebnościa, a także - jak się wydaje - uszczerbek niemajątkowy, lecz jedynie odnoszący się do niedogodności czy dyskomfortu właściciela nieruchomości w związku z wykonywaniem służebności. Należy przyjmować, że wynagrodzenie za służebność jest należne, nawet jeżeli właściciel nieruchomości nie doznał szkody ${ }^{29}$, a gdy powstał po jego stronie uszczerbek w związku z posadowionymi urządzeniami (co zazwyczaj będzie miało miejsce), pełni ono, podobnie jak odszkodowanie, funkcję kompensacyjną wobec niego. Zakres uszczerbków kompensowanych wynagrodzeniem za służebność przesyłu zostanie szczegółowo omówiony w pkt IV niniejszego artykułu.

\section{ZAKRES USZCZERBKÓW KOMPENSOWANYCH WYNAGRODZENIEM ZA SŁUŻEBNOŚĆ PRZESYŁU}

Doniosłe z punktu widzenia praktyki jest określenie zakresu uszczerbków kompensowanych wynagrodzeniem za służebność przesyłu. Wynagrodzenie za służebność, zgodnie z art. $305^{2}$ k.c., powinno być odpowiednie, słusznie wskazuje się przy tym, że zarówno dla właściciela nieruchomości, jak i przedsiębiorcy przesyłowego ${ }^{30}$. Kodeks cywilny nie definiuje pojęcia odpowiedniego wynagrodzenia. Odnosząc się do definicji zawartej w Wielkim słownika języ-

${ }^{25}$ Tak m.in. postanowienie SN z 19 października 2013 r., V CSK 491/12, Lex nr 1394096.

${ }^{26}$ Por. Karaszewski (2014): $89 \mathrm{n}$.

${ }^{27}$ Tak m.in. Matusik (2013): 400; Zaradkiewicz (2018): 979.

${ }^{28} \mathrm{~W}$ orzecznictwie wyrażono tezę, że uszczerbek właściciela związany z pogorszeniem nieruchomości w następstwie posadowienia na niej urządzeń elektroenergetycznych jest rekompensowany świadczeniem, jakie może uzyskać za obciążenie jego prawa służebnością przesyłu - tak postanowienie SN z 27 lutego 2013 r., IV CSK 440/12, Lex nr 1294169; podobnie wyrok SA w Łodzi z 23 lutego 2016 r., I ACa 1238/15, Lex nr 2005579; zob. także postanowienie SN z 6 kwietnia 2018 r., IV CSK 540/17, Lex nr 2497679.

${ }^{29}$ Tak też słusznie SN w uzasadnieniu postanowienia z 20 kwietnia 2017 r., II CSK 505/16, Lex nr 2331704.

${ }^{30}$ Rakoczy (2009): 96. 
ka polskiego, trzeba odnotować, że termin „odpowiedni” znaczy „taki, jaki powinien być $\mathrm{w}$ danej sytuacji”. W konsekwencji należy przyjmować, że wynagrodzenie za służebność przesyłu kompensuje wszystkie te uszczerbki, które powstały po stronie właściciela nieruchomości jako następstwo ustanowienia służebności przesyłu. Obejmuje ono więc wszystkie zwyczajne następstwa związane z dokonana inwestycją przesyłowa, czyli uszczerbki doznane przez właściciela nieruchomości stanowiące bezpośredni i typowy skutek jej wykonywania. Takie ujęcie zakresu kompensowanych uszczerbków odpowiada terminowi „odpowiednie wynagrodzenie” z art. $305^{2} \S 2$ k.c.

Nie można jednak w całej rozciagłości podzielić zapatrywania, iż wynagrodzenie za służebność powinno uwzględniać cały uszczerbek, który jest następstwem ustanowienia służebności ${ }^{31}$. Niektóre szkody, przykładowo te wynikłe z nadzwyczajnych zdarzeń (np. zniszczenia w mieniu dokonane w związku z usuwaniem awarii czy uszkodzenia związane z pożarem urządzeń przesyłowych) nie byłyby rekompensowane, albowiem pojęcie odpowiedniego wynagrodzenia odnosi się w naszej ocenie, jedynie do zwyczajnych skutków ustanowienia służebności, a w konsekwencji typowych następstw realizowanej inwestycji przesyłowej. Owe uszczerbki mogą powstać na dwóch etapach. Po pierwsze, na etapie budowy urządzeń, o ile uprawnienie do budowy będzie objęte zakresem służebności, co dotyczyć będzie nowych inwestycji przesyłowych $^{32}$. Po drugie, na płaszczyźnie związanej z utrzymywaniem urządzeń, co dotyczy każdej ustanawianej służebności przesyłu.

Nie można jednak przy tej okazji pominąc istotnej dystynkcji, mającej wpływ na ustalenie zakresu uszczerbku kompensowanego wynagrodzeniem za ustanowienie służebności przesyłu. Rozróżnienie to odnosi się do rodzajów ustanawianych służebności przesyłu. Inny będzie uszczerbek, a tym samym wynagrodzenie $\mathrm{w}$ sytuacji ustanowienia służebności przesyłu gazu, paliw płynnych oraz energii elektrycznej, inny zaś w przypadku pozostałych rodzajów służebności (np. sieci wodno-kanalizacyjnych czy ciepłowniczych). Jest to związane z rodzącym praktyczne trudności określeniem obszaru służebności. Przypomnieć bowiem należy, że granice pasa służebności sa, po pierwsze, wyznaczone szerokością samych urządzeń przesyłowych, znajdujących się pod lub nad poziomem gruntu oraz obszarem gruntu niezbędnym do budowy (jeżeli ustanowienie służebności przesyłu ma nastapić przed budową urządzenia przesyłowego), a następnie utrzymania, eksploatacji i konserwacji urządzenia. Jest to tzw. pas eksploatacyjny, inaczej nazywany pasem technologicznym. Z uwagi jednak na ograniczenia właściciela nieruchomości wynikające ze względów bezpieczeństwa, niezbędne może się okazać ustanowienie tzw. strefy ochronnej, którą także należy zaliczać do treści służebności ${ }^{33}$. W kon-

31 Tak postanowienie SN z 29 maja 2015 r., V CSK 468/14, Lex nr 1793714. Podobnie m.in. w postanowienie SN z 20 września 2012 r., IV CSK 56/12, Lex nr 1227856.

32 Służebność przesyłu może być ustanowiona dla istniejących już urządzeń przesyłowych, w takim przypadku uprawnienie do ich wybudowania nie będzie stanowić elementu treści tego prawa.

${ }^{33}$ Zob. uzasadnienie wyrok SN z 14 listopada 2013 r., II CSK 69/13, OSNC 2014, nr 9, poz. 91; uzasadnienie postanowienie SN z 20 kwietnia 2017 r., II CSK 505/16, Legalis nr 1657564. 
sekwencji przy ustalaniu wysokości wynagrodzenia należy brać pod uwagę obszary oddziaływania urządzenia przesyłowego ${ }^{34}$.

W aktualnie obowiązującym porządku prawnym szczegółowe przepisy regulujące określenie strefy ochronnej odnoszą się wyłącznie do urządzeń przesyłu gazu ${ }^{35}$ oraz paliw płynnych ${ }^{36}$. W przypadku natomiast urządzeń przesyłowych elektroenergetycznych brak przepisów, które by wprost regulowały zagadnienie stref ochronnych. Pomimo braku stosownych uregulowań także i w tym przypadku strefa taka winna być uwzględniania przy ustalaniu pasa służebności i obejmować bezpieczny bufor z punktu widzenia zakresu szkodliwego promieniowania elektromagnetycznego wynikającego z używania urządzeń energetycznych ${ }^{37}$. Nie można tutaj ustalić sztywnych norm, chociaż posiłkowo uzasadnione jest odwoływanie do ustaleń miejscowego planu zagospodarowania przestrzennego, o ile takowy został na danym terenie uchwalony, jeżeli np. przewiduje zakaz budowy wzdłuż linii infrastruktury technicznej. Możliwe jest także odwołanie się per analogiam do innych przepisów odnoszących się na przykład do wykonywania robót budowlanych w obrębie urządzeń przesyłowych ${ }^{38}$. Skoro bowiem nie jest możliwe na określonym obszarze prowadzenie robót budowlanych, które zawsze wszak wiążą się z sytuowaniem w miejscu budowy stanowisk pracy, składowisk wyrobów i materiałów oraz maszyn i urządzeń budowlanych, to można z tego wyciagnąć wniosek o ograniczeniu możliwości korzystania z tej powierzchni w sposób bezpośredni przez właściciela nieruchomości obciążonej. Ograniczenie korzystania z nieruchomości pozostaje w ścisłym, nierozerwalnym związku z usytuowaniem linii energetycznej przebiegającej przez nieruchomość.

W celu wyznaczenia strefy ochronnej konieczne może się okazać - jeżeli ustanowienie służebności przesyłu odbywa się na drodze sądowej - powołanie dowodu z opinii biegłego sądowego z zakresu danej specjalności, w zależności od tego, czy chodzi o urządzenia przesyłowe energetyczne, gazowe bądź paliw płynnych. W przypadku przedsiębiorcy ciepłowniczego, wodno-kanalizacyjnego czy telekomunikacyjnego w sytuacji braku szczególnych regulacji, także może okazać się niezbędne skorzystanie $\mathrm{z}$ wiadomości specjalnych (art. 278 k.p.c.), o ile zachodzić będą wątpliwości co do określenia szerokości pasa służebności, ustalanego zazwyczaj w tego typu sprawach w sposób wystarczajacy przez biegłego z zakresu geodezji i kartografii. W konsekwencji, w zależności od rodzaju urządzeń przesyłowych będących przedmiotem służebności przesyłowej, pas służebności, uwzględniając ukształtowaną w tej mierze praktykę,

${ }^{34}$ Tak trafnie np. SN w postanowienie z 6 kwietnia 2018 r., IV CSK 540/17, Lex nr 2497679.

35 Rozporządzenie Ministra Gospodarki z 26 kwietnia 2013 r. w sprawie warunków technicznych, jakim powinny odpowiadać sieci gazowe i ich usytuowanie, Dz. U. 2013, poz. 640; zob. także Matusik (2013): 413-414.

${ }^{36}$ Rozporządzenie Ministra Gospodarki z 21 listopada 2005 r. w sprawie warunków technicznych, jakim powinny odpowiadać bazy i stacje paliw płynnych, rurociagi przesyłowe dalekosiężne służące do transportu ropy naftowej i produktów naftowych i ich usytuowanie, t.jedn.: Dz. U. 2014, poz. 1853 ze zm.; zob. także Matusik (2013): 413-414.

37 Podobnie Matusik (2013): 413-414.

${ }^{38} \mathrm{~Np}$. do $§ 55$ rozporządzenia Ministra Infrastruktury z 6 lutego 2003 r. w sprawie bezpieczeństwa higieny pracy podczas wykonywania robót budowlanych, Dz. U. Nr 47, poz. 401. 
będzie obejmował albo wyłącznie pas umożliwiający przedsiębiorcy wykonywanie niezbędnych czynności zapewniających prawidłową eksploatację urządzeń, czyli tzw. pas technologiczny (eksploatacyjny, pas służebności sensu stricto), co najczęściej będzie występowało w odniesieniu do służebności dotyczących urządzeń telekomunikacyjnych, ciepłowniczych lub wodno-kanalizacyjnych bądź też dodatkowo będzie obejmował obszar, w którym właściciel nieruchomości doznaje dodatkowych ograniczeń ze względów bezpieczeństwa, nazywany pasem ochronnym (pas służebności sensu largo).

Dopiero po ustaleniu właściwego pasa służebności oznaczonego przez biegłego z zakresu geodezji i kartografii na mapie, stanowiącej podstawę ujawnienia służebności w księdze wieczystej, aktualizuje się obowiązek przeprowadzenia dowodu $\mathrm{z}$ opinii biegłego sądowego o specjalności adekwatnej do ustalenia wysokości wynagrodzenia za ustanowienie służebności przesyłu.

\section{Płaszczyzna dotycząca budowy urządzeń przesyłowych}

W ramach płaszczyzny budowy urządzeń przesyłowych wynagrodzenie za służebność pokrywa, po pierwsze, uszczerbki majątkowe (damnum emergens) doznane przez właściciela nieruchomości w związku z procesem posadowienia urządzeń przesyłowych na danej nieruchomości, i to zarówno takie, które powstały w zakresie ustanowionego pasa służebności, jak i w odniesieniu do tzw. stref ochronnych, gdy budowa będzie służyła przesyłowi gazu, paliw płynnych lub energii elektrycznej. Uszczerbkami związanymi z ingerencją w substancję rzeczy związaną z budową urządzeń przesyłowych są typowe uszkodzenia istniejących, zwyczajnych nasadzeń (np. w postaci upraw istniejących zbóż, utraty powierzchni pastwiska, powierzchni do zabudowy itp.) czy typowe uszkodzenia istniejącej, zwyczajnej zabudowy (np. związane z koniecznościa rozbiórki obiektów gospodarskich, jeżeli szkody te powstaną w toku prawidłowo wykonywanego procesu inwestycyjnego - ze swej istoty naruszajacego substancję nieruchomości obciążonej). Natomiast nie są kompensowane wynagrodzeniem za służebność przesyłu uszkodzenia nietypowe, a więc po pierwsze takie, które nie są zwyczajną konsekwencją procesu inwestycyjnego (np. zniszczenia, które powstały co najmniej na skutek niedbalstwa, ale także przypadkowe zniszczenia związane z ryzykiem prowadzenia działalności przez przedsiębiorce przesyłowego), oraz szkody w uprawach czy zabudowie szczególnego rodzaju, np. uszkodzenie drogich gatunków roślin czy urządzeń o szczególnym charakterze (np. obiekty architektury ogrodowej czy obiekty użytkowe służące codziennej rekreacji).

Po drugie, pomimo że zagadnienie to jest sporne ${ }^{39}$, opowiadamy się za stanowiskiem, że wynagrodzenie za służebność przesyłu pokrywa również obniżenie wartości nieruchomości. Tenże spadek wartości stanowi konsekwencję uznania nieruchomości jako zabudowanej urządzeniami przesyłowymi, z obciążeniem ograniczonym prawem rzeczowym ujawnionym w dziale III księgi

39 Zob. na ten temat Balwicka-Szczyrba (2015): 140; zob. także uzasadnienie postanowienie SN z 28 maja 2019 r., II CSK 585/18, Lex nr 2683398. 
wieczystej dla niej prowadzonej ${ }^{40}$. Należy bowiem przyjmować, iż skoro omawiane wynagrodzenie jest wynagrodzeniem „za służebność”, to zarówno za ustanowienie tego prawa, jak i wszystkie konsekwencje jego ustanowienia, $\mathrm{w}$ tym konsekwencje prawne i gospodarcze związane $\mathrm{z}$ istnieniem urządzeń. $\mathrm{W}$ świetle art. $305^{2}$ k.c. nie znajduje uzasadnienia wyodrębnianie niektórych typowych uszczerbków doznanych w związku z ustanowieniem służebności, od innych, i poddanie roszczeń o ich naprawienie odmiennym zasadom kodeksowym. Niewątpliwie spadek wartości nieruchomości jest normalną konsekwencją ustanowienia służebności, a przez to jest pokrywany wynagrodzeniem za służebność. Przyjęte zapatrywanie znajduje odzwierciedlenie w orzecznictwie. Między innymi w postanowieniu SN z 20 kwietnia 2017 r. ${ }^{41}$ podkreślono, iż odpowiednie wynagrodzenie za ustanowienie służebności przesyłu powinno być ustalone proporcjonalnie do stopnia ingerencji w treść prawa własności, uwzględniać wartość nieruchomości i w takim kontekście mieć na względzie szkodę właściciela z uszczuplenia prawa własności. Podobnie w postanowieniu SN z 20 września $2012 \mathrm{r}^{42}$ wskazano, że wynagrodzenie należne na podstawie art. $305^{2} \S 2$ k.c. powinno obejmować zmniejszenie wartości nieruchomości. Z kolei w uzasadnieniu postanowienia SN z 28 maja 2019 r. podkreślono, że uszczerbek spowodowany ustanowieniem służebności przesyłu może być obliczony na podstawie różnicy między wartością nieruchomości bez obciążenia a wartością uwzględniająca obciążenie spowodowane ustanowieniem służebności ${ }^{43}$.

\section{Płaszczyzna dotycząca utrzymywania urządzeń przesyłowych}

W ramach płaszczyzny związanej z utrzymywaniem urządzeń przesyłowych na cudzej nieruchomości przez przedsiębiorców przesyłowych uszczerbki po stronie właściciela nieruchomości powstają zazwyczaj w związku z ograniczeniami dotyczącymi korzystania z nieruchomości, zarówno w obszarze posadowienia urządzeń, jak i wyznaczonych pasów służebności ${ }^{44}$. Odpowiednie wynagrodzenie za służebność przesyłu powinno pokrywać typowe uszczerbki majątkowe, a także inne dolegliwości związane $\mathrm{z}$ istnieniem urządzeń przesyłowych. Pokrywa także uszczerbki niemajątkowe, lecz jedynie w zakresie odnoszącym się do niedogodności czy dyskomfortu dla właściciela gruntu obciążonego, wynikających z samej konieczności znoszenia istniejącej zabudowy urządzeniami przesyłowymi.

Rozmiar doznawanych przez właściciela nieruchomości uszczerbków majątkowych zależy przede wszystkim od rodzajów posadowionych urządzeń przesyłowych, a także rodzaju nieruchomości, na której są ona posadowione ${ }^{45}$.

${ }^{40}$ Podobnie w zakresie służebności drogi koniecznej - Karaszewski (2014): 94.

${ }^{41}$ Postanowienie SN 20 kwietnia 2017 r., II CSK 505/16, Lex nr 2331704.

${ }^{42}$ IV CSK 56/12, Lex nr 1227856.

${ }^{43}$ II CSK 585/18, Lex nr 2683398.

${ }^{44}$ Por. Jankowska (2018): 722.

${ }^{45}$ Co do „wskazówek”, według których należy ustalić wysokość wynagrodzenia za ustanowienie służebności przesyłu, zob. m.in. postanowienia SN: z 5 kwietnia 2012 r., II CSK 401/11, Lex 
Jest on stosunkowo niewielki w przypadkach dotyczących urządzeń podziemnych, takich jak sieci wodno-kanalizacyjne czy rury ciepłownicze. W takich sytuacjach konsekwencje po stronie właściciela nieruchomości związane z lokalizacją urządzeń przesyłowych polegają zazwyczaj jedynie na ograniczeniach związanych z zabudową nieruchomości czy dokonaniem uciążliwych nasadzeń w pasie służebności sensu stricto, obejmującym wyłącznie pas technologiczny (eksploatacyjny). Grunt, w którym znajdują się urządzenia, może być najczęściej wykorzystywany w celach rolniczych czy parkingowych. Nieco inaczej jest w odniesieniu do urządzeń podziemnych służących do przesyłu gazu lub paliw płynnych. Wówczas ograniczenie jest szersze i wynika ze wspomnianych wcześniej względów bezpieczeństwa. Ograniczenia zabudowy i ewentualnych nasadzeń (np. drzew) dotyczą wówczas pasa służebności sensu largo, obejmującego także strefy ochronne. W praktyce obliczania wynagrodzenia uwzględnia się to przez określenie tzw. współczynnika współkorzystania z nieruchomości przez właściciela nieruchomości obciążonej oraz przedsiębiorcę przesyłowego.

W przypadku urządzeń naziemnych zakres korzystania przez przedsiębiorcę przesyłowego z cudzej nieruchomości jest większy i także zależy od rodzaju urządzenia przesyłowego, a zwłaszcza jego wielkości. Słupy energetyczne wysokich napięć w większym stopniu ograniczają korzystanie z nieruchomości przez właściciela niż urządzenia dystrybucyjne niskich napięć, a tym samym moga powodować powstanie uszczerbku majątkowego o większym rozmiarze, obejmującego np. utracone korzyści (lucrum cessans) doznane przez właściciela nieruchomości obciążonej w związku z niemożnością uzyskiwania plonów z zajętego przez urządzenie przesyłowe obszaru.

$\mathrm{Na}$ rozmiar uszczerbków doznawanych przez właściciela nieruchomości wpływ ma także jej przeznaczenie. Jeżeli jest to nieruchomość rolnicza, z przeznaczeniem pod produkcję roślinna, to posadowienie urządzeń podziemnych nie wywołuje w zasadzie większych uszczerbków dla jej właściciela, a ponadto jest zazwyczaj jedynie w niewielkim stopniu uciążliwe. Z kolei urządzenia naziemne są uciążliwe zazwyczaj w takim stopniu, w jakim wyłączają obszar pod urządzeniami z produkcji, a także utrudniają pracę maszyn rolniczych. Większy zakres uciążliwości związany jest z urządzeniami wybudowanymi na nieruchomościach przeznaczonych pod zabudowę, zwłaszcza gdy sposób ich lokalizacji wyłącza bądź istotnie ogranicza dany sposób zabudowy ustalony na przykład w miejscowym planie zagospodarowania przestrzennego. W konsekwencji uszczerbek majątkowy, jakiego może doznać właściciel nieruchomości, jest zazwyczaj większego rozmiaru niż w przypadku urządzeń podziemnych i obejmuje wskazane wcześniej utracone korzyści.

Kolejnym czynnikiem wpływajacym na rozmiar uszczerbków, które moga powstać w związku z budową urządzeń przesyłowych, jest położenie nieruchomości. Wynagrodzenie za służebność będzie wyższe w przypadku nieruchomości miejskich bądź innych nieruchomości o lepszym, bardziej atrakcyjnym położeniu, albowiem uszczerbek majątkowy związany z istnieniem urządzeń 
przesyłowych na takich nieruchomościach będzie większy. Pomimo to należy akcentować, że wysokość omawianego wynagrodzenia nie powinna przekraczać wartości obciążonej nieruchomości ${ }^{46}$.

$\mathrm{Z}$ istoty ustalonego pasa służebności wynika także, że wynagrodzenie co do zasady obejmuje także uszczerbek związany z każdorazowym przejściem lub przejazdem przez nieruchomość w celu dostępu do urządzenia przesyłowego.

Nie wszystkie jednak uszczerbki na mieniu właściciela nieruchomości, związane z utrzymywaniem urządzeń przesyłowych, będą kompensowane wynagrodzeniem za służebność przesyłu, a jedynie te bezpośrednio wynikające z wykonywania służebności. W szczególności wynagrodzenie za służebność przesyłu nie obejmuje uszczerbków przypadkowych (np. uszkodzeń mienia $\mathrm{w}$ związku z zapaleniem się instalacji energetycznej) czy uszczerbków niezwiąanych bezpośrednio z wykonywaniem służebności (np. szkód na mieniu powstałych na skutek usuwania awarii bądź dokonywania modernizacji sieci). Nadto zgodnie z tym, co już wskazano, omawiane wynagrodzenie nie obejmuje uszczerbków na mieniu znajdującym się poza określonym pasem służebności.

\section{PODSUMOWANIE}

Rozważania dokonane w niniejszym opracowaniu wskazuja, że wynagrodzenie za służebność przesyłu ma dwojakiego rodzaju charakter: nie tylko przysługuje za samo ustanowienie służebności - niezależnie od tego, czy właściciel nieruchomości doznał szkody - lecz także ma charakter odszkodowawczy, a zatem pokrywa uszczerbki majątkowe i niemajątkowe doznane przez właściciela nieruchomości $\mathrm{w}$ związku z ustanowioną służebnością. Zakres kompensowanych uszczerbków na dwóch płaszczyznach - budowy oraz utrzymywania urządzeń na nieruchomości - został w pracy szczegółowo scharakteryzowany i określony.

Powyższa teza prowadzi w konsekwencji do wniosku, że w większości przypadków zapłata wynagrodzenia za ustanowienie służebności przesyłu czyni niezasadnym wystapienie z roszczeniem odszkodowawczym za szkodę związaną z posadowieniem i istnieniem urządzeń na nieruchomości, o ile doznany uszczerbek jest bezpośrednim i typowym skutkiem ustanowienia służebności przesyłu. Jedynie w szczególnych okolicznościach osobie poszkodowanej przysługiwałoby roszczenie o naprawienie szkody zgodnie z deliktowa podstawa odpowiedzialności, gdy doznany uszczerbek majątkowy nie należy do typowych konsekwencji budowy, czy istnienia urządzeń przesyłowych na cudzej nieruchomości (np. w co do szkody doznanej w związku z awarią urządzeń), a nadto w zakresie uszczerbków doznanych poza pasem służebności.

${ }^{46}$ Tak m.in. postanowienia SN: z 5 kwietnia 2012 r., II CSK 401/11, Lex nr 1211144; z 19 października 2013 r., V CSK 491/12, Lex nr 1394096. 
Przeprowadzone rozważania pozwalają także uznać za błędną praktykę domagania się odszkodowania - ponad kwotę ustalonego wynagrodzenia za ustanowienie służebności przesyłu - za uszczerbki związane ze spadkiem wartości nieruchomości obciążonej.

\author{
Matgorzata Balwicka-Szczyrba \\ Uniwersytet Gdański \\ m.balwicka@prawo.ug.edu.pl \\ https://orcid.org/0000-0002-7981-5602 \\ Leszek Jantowski \\ Sędzia sqdu apelacyjnego \\ leszekjantowski17@gmail.com \\ https://orcid.org/0000-0002-9160-3522
}

Balwicka-Szczyrba, M. (2015). Korzystanie z nieruchomości przez przedsiębiorców przesyłowych - właścicieli urządzeń przesyłowych. Warszawa.

Jankowska, M. (2018). [Komentarz do art. 305¹], [w:] M. Habdas, M. Fras (red.), Kodeks cywilny. Komentarz. Tom 2: Własność i inne prawa rzeczowe. Warszawa: 722-723.

Jędrejek, G. (2009) Roszczenia związane z budową urządzeń przesyłowych na cudzym gruncie. Monitor Prawniczy 1: 26-27.

Konieczny, D., Kowalczyk, C. (2010). Wynagrodzenia i odszkodowania w relacjach między przedsiębiorstwami przesyłowymi lub dystrybucyjnymi a właścicielami lub użytkownikami wieczystymi nieruchomości na tle proponowanych zmian do ustawy - kodeks cywilny. Rejent 9(233): 57-68.

Karaszewski, G. (2014). Sąsiedztwo nieruchomości. Komentarz, [w:] M. Balwicka-Szczyrba, G. Karaszewski, A. Sylwestrzak. Sąsiedztwo nieruchomości. Komentarz. Warszawa: 89-94.

Kubas, A. (1966). Ustanowienie służebności drogi koniecznej. Nowe Prawo 3(237): 339-350.

Lewandowski, P. (2014). Służebność przesyłu w prawie polskim. Warszawa.

Matusik, G. (2013). Własność urządzeń przesyłowych a prawa do gruntu. Warszawa.

Radziwilski, T. (2011). Wynagrodzenie za korzystanie z nieruchomości obciążonej po zasiedzeniu służebności przesyłu. Rejent 10(246): 125-133.

Rakoczy, B. (2009). Służebność przesyłu w praktyce. Warszawa.

Warciński, M. (2010). Wynagrodzenie za ustanowienie służebności drogi koniecznej. Państwo i Prawo 65(7): 57-67.

Wdowiak, M. (2010). O wartości prawa służebności przesyłu - uwagi de lege lata i de lege ferenda [w:] Proces inwestycyjno-budowlany. Administracyjnoprawne wyzwania dla ustawodawcy. Kraków: 157-167.

Zaradkiewicz K. (2018). [Komentarz do art. $305^{2}$ k.c.], [w:] K. Pietrzykowski (red.), Kodeks cywilny. Komentarz. Tom 1: Art. 1-44910. Warszawa: 976-984.

\title{
THE COMPENSATORY NATURE OF REMUNERATION FOR A TRANSMISSION EASEMENT
}

Sum mary

The central argument in this paper is that remuneration for a transmission easement is of a compensatory nature, and is therefore paid in reimbursement of damage suffered by the property owner as a result of the established easement. What follows from this is that the payment of remuneration for establishing a transmission easement bars any claims for compensation for damage arising from the placement and existence of transmission facilities on the land plot, to the extent that such damage is the direct and typical result of the transmission easement being established. It is only in special circumstances, such as where the damage to property does not 
represent a typical consequence of the construction or existence of transmission facilities on another's land (for instance in the case of a fault in the transmission devices) and the damage has occurred outside the easement area, that the aggrieved party is entitled to seek damages in tort. The arguments presented in this paper also prove the illegitimacy of seeking compensation in excess of the amount of remuneration for a transmission easement for damage suffered as a result of the encumbered property's devaluation.

Keywords: transmission easement; remuneration for a transmission easement 